\title{
A scoping review of methods for assessment of sex differentials in early childhood mortality
}

\author{
Janaína Calu Costa ${ }^{*}$ id and Cesar G. Victora@
}

\begin{abstract}
Background: While assessment of sex differentials in child mortality is straightforward, their interpretation must consider that, in the absence of gender bias, boys are more likely to die than girls. The expected differences are also influenced by levels and causes of death. However, there is no standard approach for determining expected sex differences.
\end{abstract}

Methods: We performed a scoping review of studies on sex differentials in under-five mortality, using PubMed, Web of Science, and Scopus databases. Publication characteristics were described, and studies were grouped according to their methodology.

Results: From the 17,693 references initially retrieved we included 154 studies published since 1929. Indian, Bangladeshi, and Chinese populations were the focus of $44 \%$ of the works, and most studies addressed infant mortality. Fourteen publications were classified as reference studies, as these aimed to estimate expected sex differentials based upon the demographic experience of selected populations, either considered as gender-neutral or not. These studies used a variety of methods - from simple averages to sophisticated modeling - to define values against which observed estimates could be compared. The 21 comparative studies mostly used life tables from European populations as standard for expected values, but also relied on groups without assuming those values as expected, otherwise, just as comparison parameters. The remaining 119 studies were categorized as narrative and did not use reference values, being limited to reporting observed sex-specific estimates or used a variety of statistical models, and in general, did not account for mortality levels.

Conclusion: Studies aimed at identifying sex differentials in child mortality should consider overall mortality levels, and report on more than one age group. The comparison of results with one or more reference values, and the use of statistical testing, are strongly recommended. Time trends analyses will help understand changes in population characteristics and interpret findings from a historical perspective.

Keywords: Gender bias, Excess female mortality, Under-five mortality, Epidemiology, Review

\footnotetext{
*Correspondence: jcosta@equidade.org

International Center for Equity in Health, Postgraduate Program in Epidemiology, Federal University of Pelotas. Marechal Deodoro, 1160, 3rd floor, Pelotas 96020-220, Brazil
}

(c) The Author(s). 2021 Open Access This article is licensed under a Creative Commons Attribution 4.0 International License, which permits use, sharing, adaptation, distribution and reproduction in any medium or format, as long as you give appropriate credit to the original author(s) and the source, provide a link to the Creative Commons licence, and indicate if changes were made. The images or other third party material in this article are included in the article's Creative Commons licence, unless indicated otherwise in a credit line to the material. If material is not included in the article's Creative Commons licence and your intended use is not permitted by statutory regulation or exceeds the permitted use, you will need to obtain permission directly from the copyright holder. To view a copy of this licence, visit http://creativecommons.org/licenses/by/4.0/ The Creative Commons Public Domain Dedication waiver (http://creativecommons.org/publicdomain/zero/1.0/) applies to the data made available in this article, unless otherwise stated in a credit line to the data. 


\section{Key findings and recommendations}

- There is no standard method for assessing sex differentials in under-five mortality in order to identify unexpected sex ratios that may suggest the presence of gender bias.

- The identification of unexpected sex ratios will vary depending on the assumptions and methods used to define expected values.

- The historical demographic experiences of currently high-income countries provide the main reference parameters for the assessment of sex differentials, but different epidemiological profiles are present in current-day populations.

- Most studies failed to consider the overall level of mortality, relied upon a single expected value for multiple countries, and did not report on statistical assessments of the differences between observed and expected estimates.

- The use of external parameters for comparison that consider the level of overall mortality and apply appropriate statistical methods to compare observed and expected ratios are recommended.

- Whereas gender bias against girls is the most frequent explanation for unexpected sex ratios, methods should also consider the possibility of higher-than-expected mortality of boys.

\section{Background}

Mortality is a result of the interaction between several complex factors such as genetics, environment, health care, and behaviors, and there is overwhelming evidence that male children have a higher risk of death than do females [1-3]. Nevertheless, there are many historical examples of excess female mortality at specific periods of the life course from childhood through adulthood [4-7].

Due to biological characteristics, female newborns and infants have an advantage in survival and enjoy lesser vulnerability to mortality due to perinatal conditions, congenital anomalies, and infectious diseases [8-10]. Beyond the first year of life, girls do not present the same advantage concerning certain infectious diseases, which are the primary causes of death from 1 to 4 years of age, and this advantage remains but tends to decline $[1,2]$. Even so, in circumstances in which boys and girls receive the same care, higher mortality among male children is observed and equality in male and female death rates (or higher female mortality) may be evidence of inequity [11].

Excess female mortality may be an indicator of influences that outweigh the biological survival advantages of girls [1]. For instance, in some populations, the female advantage can be eroded if girls are deprived of access to health care or proper nutrition, suggesting discriminatory behaviors and gender bias in child care due to community male preference $[1,12]$.

Although sex differentials in early childhood mortality are recognized as important issues globally, there is no consensus about what would be expected in the absence of discrimination. A further challenge is that the magnitude of differences will vary according to total mortality levels and to the distribution of causes of death $[8,11,13]$.

Many studies have assessed differences in mortality between boys and girls and sets of reference values for the relationship between the sex-specific estimates have been proposed, however, there is not a standard method for such analyses. In particular, the literature still lacks a proper description of how the estimates for such variations had been defined. By bringing together the approaches used so far and using a scoping review methodology, we described how studies addressed sex differentials in early childhood mortality with a special focus on the methods used to measure such discrepancies.

\section{Methods}

Data sources and search strategy

We conducted searches on PubMed, Web of Science, and Scopus electronic databases for potentially relevant publications on sex differentials in mortality among children, with no date limits or language restrictions. The searches included combinations of the key terms "gender" and "sex" with each of the selected words that reflect differences between the groups, namely "bias", "gap", "difference", "effects", "imbalance", "inequality", "differential", "disparities", "selection", "preference", "discrimination", and "ratio", plus the words "mortality" and "child". Additionally, we undertook searches using commonly used terms for excessive deaths: "excess male", "excess female", "increased female", "excess under-5" and "excess under-five", combined with "mortality" and "child"", as well as "missing girls" and "missing women". The list of terms and the full search strategy are presented in Fig. 1.

After removing the duplicates, we reviewed titles and abstracts for inclusion and if any doubts persisted, the full publication was read and included if it met the eligibility criteria. Finally, the reference lists of selected studies were searched for further relevant works. The search ended in July 2020.

\section{Eligibility criteria}

Studies were eligible for inclusion if they quantitatively explored and discussed differentials in early child mortality by sex. These publications include any indicator of deaths of children under the age of five, videlicet, neonatal (NMR, 0-28 days of life), post-neonatal (PNMR, 28 days to 11 months and 29 days), infant (IMR, $0-11$ months), child (CMR, 1-4 years), and under-five mortality rate (U5MR, 0 


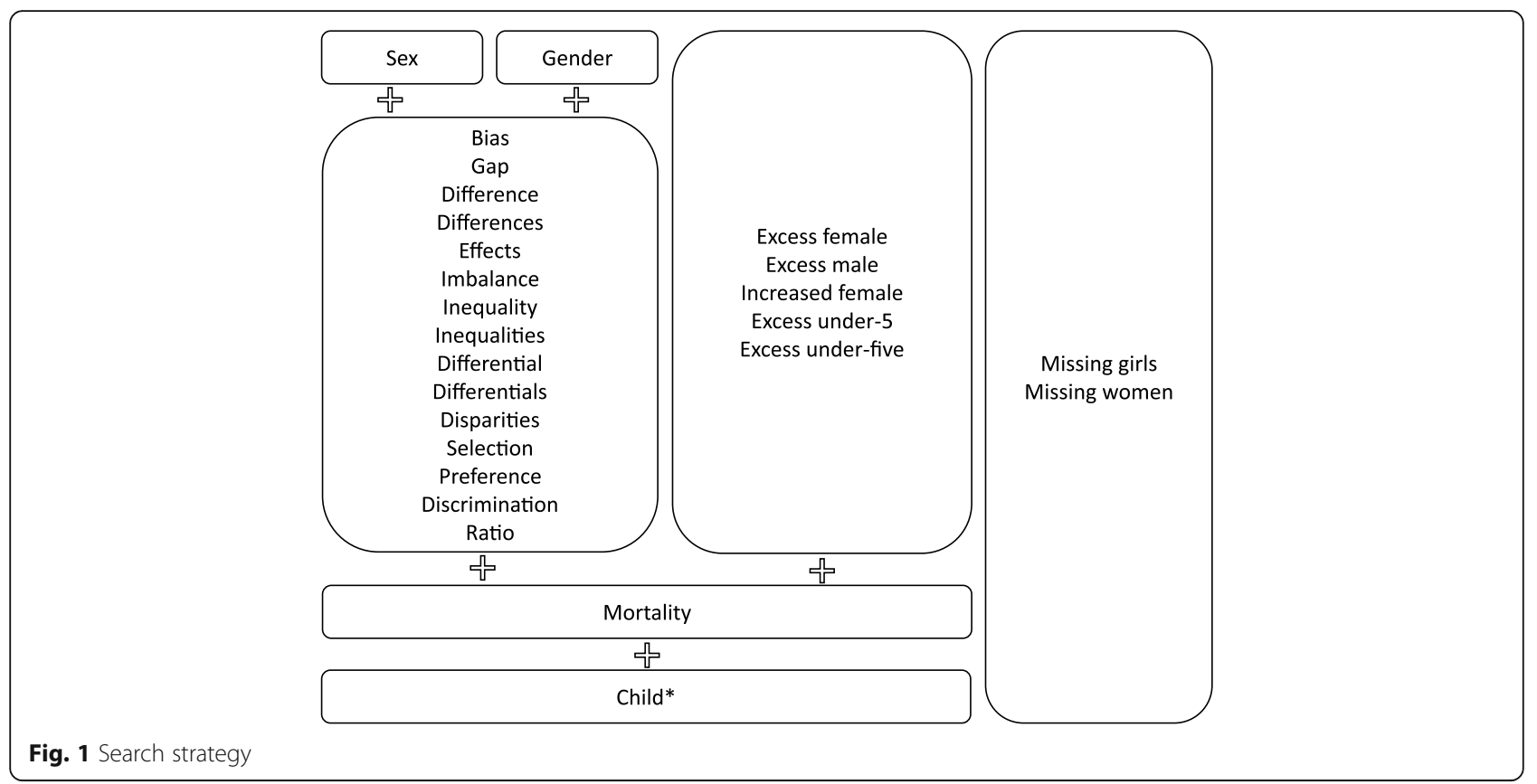

4 years), or any publication-specific age range. We excluded studies focusing on specific diseases, conditions (e.g. preterm), or behaviors (e.g. accidents and injuries), and those that only described differences in causes of death but did not report mortality levels. Also, we did not include works that addressed fetal mortality or actual population sex ratios as a measure of differential survival by sex.

\section{Article relevance screening}

For each selected reference, we extracted publication characteristics, methodology, and results of interest. Our main focuses were the methods used to measure differences in mortality between boys and girls, including the data sources used to estimate mortality and to define the comparison reference (when applicable), statistical methods for comparing sex-specific estimates and observed and expected estimates. Despite some differences with the methodology used for systematic reviews, we present the relevant information in a PRISMA checklist (Supplementary Table S1).

\section{Studies characterization}

We defined three categories of publications based on similarities in the methodological approach used in each of them.

The first category was labeled as 'Reference' and include those studies that proposed specific reference populations as parameters of comparison (e.g. a set of high-income countries, populations for which gender discrimination is assumed to be absent, or the countries from a given region) and applied well-defined methods to estimate the expected values for sex differentials in childhood mortality. The author then used the results obtained from the reference population to compare with sex-specific estimates observed in other populations.

The second category consists of 'Comparative' studies, which were those that reported a comparison of data from a specific population to a previously defined expected estimate for sex differentials mortality (e.g., published sex ratios for a given reference population) or simply comparing results from different geographies in order to describe their similarities and differences without assuming one of them as expected parameter.

The main difference between the reference and the comparative studies is that the former present a specific methodology for calculating the differential survival for boys and girls in the reference population defining expected values, while the latter group applies the methodology presented in a reference study, or else only compare results from two or more populations.

Finally, the third group includes the 'Narrative' studies, that is, those in which the authors did not use any reference or comparison standard, and simply described sex differentials in mortality based only on their data.

\section{Additional information}

Studies included in the reference group were also identified as either descriptive or prescriptive, based on a previous classification [14]. The former group includes studies that show how sex differentials in mortality vary, regardless of whether gender bias is assumed to exist, that 
is, without an a priori judgment. The latter group consists of publications in which mortality rates by sex are compared to values that would be expected in societies where gender discrimination is believed to be low or absent. Also, the number of citations for each reference study was collected from Web of Science metrics.

Based on the titles we generated a word cloud, a visual representation of text data in which the items are weighted according to their frequency. It helps us to visualize how the terms have been used in the field.

\section{Results}

Selection of studies

The initial searches yielded 17,693 publications. After removing the 4525 duplicates, 13,168 titles and abstracts were screened, and afterward, 147 articles were assessed in detail. Of these, 103 met all the inclusion criteria. From the lists of references, we found and could get access to other 51 works, resulting in 154 studies included in this review. The flow diagram displays the search strategy and study selection process (Fig. 2).

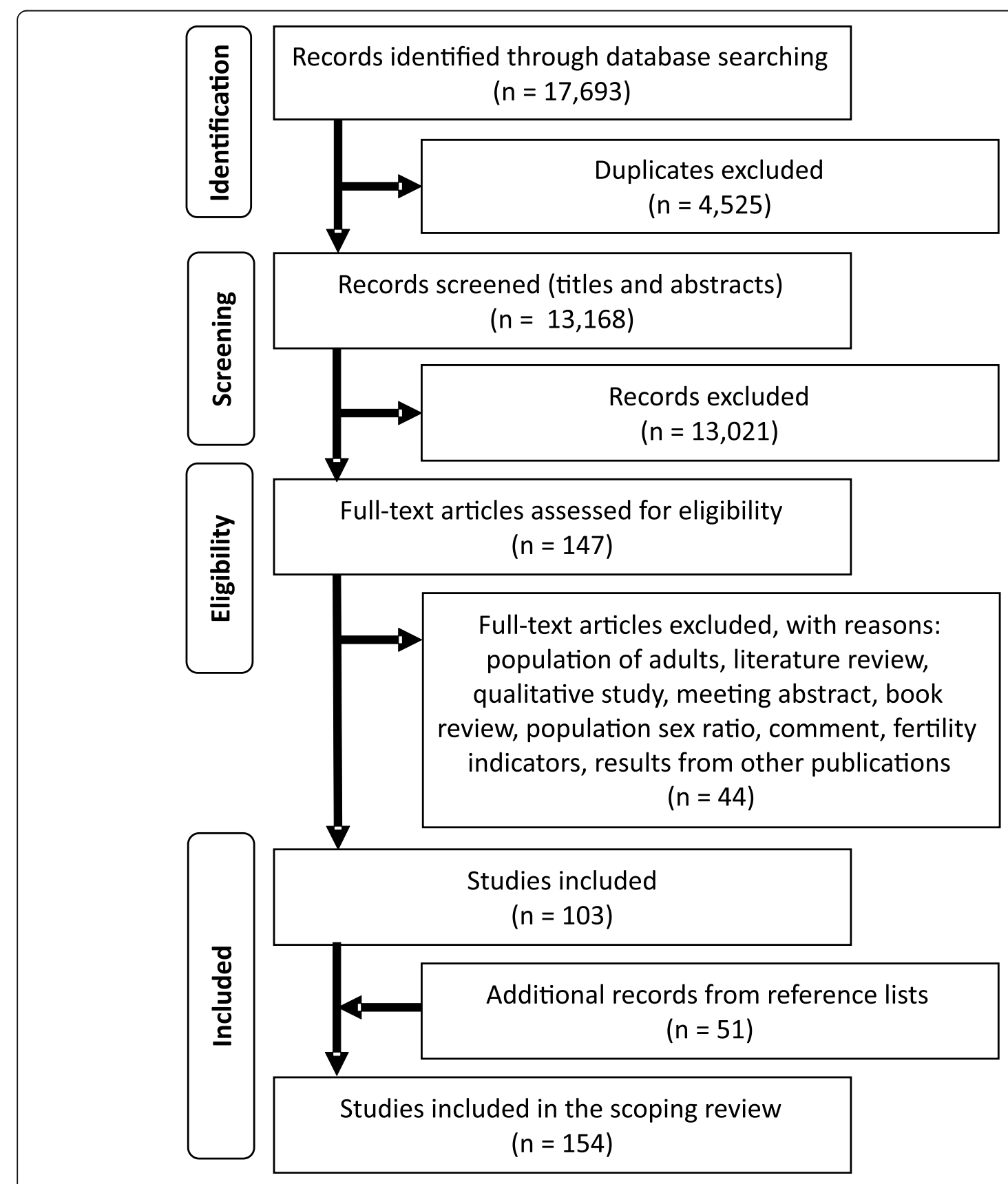

Fig. 2 Study selection flow diagram 


\section{General characteristics of studies included}

The word cloud based on titles revealed a diversity of terminologies used in the publications, especially the possible interchangeable use of "sex" and "gender" and the high frequency of studies from India (Supplementary Figure S1).

The period of mortality estimates ranged from 1700 to 2016, which may refer to the survey year, the period before the survey for which the rates were estimated, or the actual years when the deaths occurred. Many studies assessed changes over time, either by comparing two points in time or by analyzing time series with several points $[1-3,5-7,11,13,15-64]$.

The studies were published in a period between 1929 and 2020 . Up to the 1980s, there were only thirteen publications $[15,27,51,54,56,57,61,63-68]$, and the number increased to 21 in the 1980s [8, 23, 28, 34, 58, 59, 69-83], 46 in the 1990s $[3,4,6,12,22,24,33,39,43,44,46,49,52,53,84-$ 115], decreased to 30 in the 2000s [7, 11, 16, 17, 21, 25, 26, $36,41,47,50,60,62,116-132]$, and reached 44 in the period between 2010 and 2020 [1, 2, 5, 13, 14, 18-20, 29$32,35,37,38,40,42,45,48,55,133-156]$.

One hundred and eleven studies used data from single countries, mostly from India $(n=50,32 \%)$, followed by Bangladesh $(n=11,7 \%$, and all of them carried out in the Matlab region) and China $(n=7,5 \%)$. Eleven explored data from more than one country and other 27 used data from a set of countries grouped according to income level classification or geographic region, mostly low- and middleincome countries (LMICs, $n=12$ ) and sub-Saharan Africa $(n=9)$. The other five studies used global data. In Fig. 3 the area of the rectangles is proportional to the number of studies from each country or group of countries.
Estimates of mortality were derived from several sources, including civil registration systems and other official demographic statistics (29\%), censuses (18\%), and surveys (47\%). Registration data from the Human Mortality Database, the United Nations Demographic Yearbook, and other sources of life tables and national estimates from international agencies have also been used (8\%). The remaining relied on published estimates from other authors, specific studies, and experiments (16\%).

Information on child age allows more than one group to be attributed to each study. Most of the publications addressed IMR, as this was the primary measure of child survival in the past. More recently, because gender discrimination seems to be more evident in the age range of 1-4 years, the focus was moved to CMR and all under-five children. In some studies, the authors defined specific age groups for the analysis, reporting on nonstandard age groups $[5,7,24,36,37,39,46,54,72-74$, $78,80,81,83,85,86,88-90,94,99,101,108,110,111$, $114,115,117,118,126,128,139,146,149,156]$.

Some authors reported on female-to-male sex ratios for mortality, but most presented results as male-tofemale ratios, either as a simple ratio or multiplied by 100 , with values of 1 and 100, respectively, indicating equality between boys and girls. Also, in some of them, the excess mortality of girls was estimated $[2,14,18-20$, $42,93,102,109,132,153,154]$.

\section{Methodological characteristics \\ Reference studies}

Fourteen publications defined expected values for sex ratios or sex-specific mortality based on the experience of particular populations, being categorized as reference

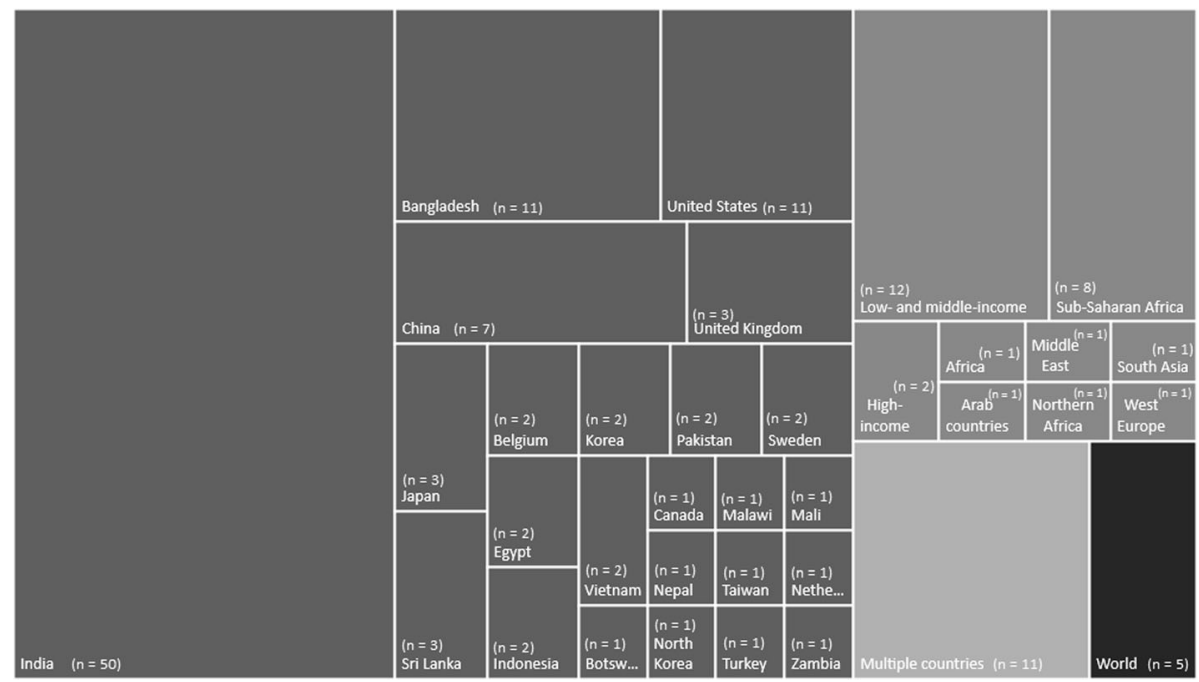

Fig. 3 Place under study 


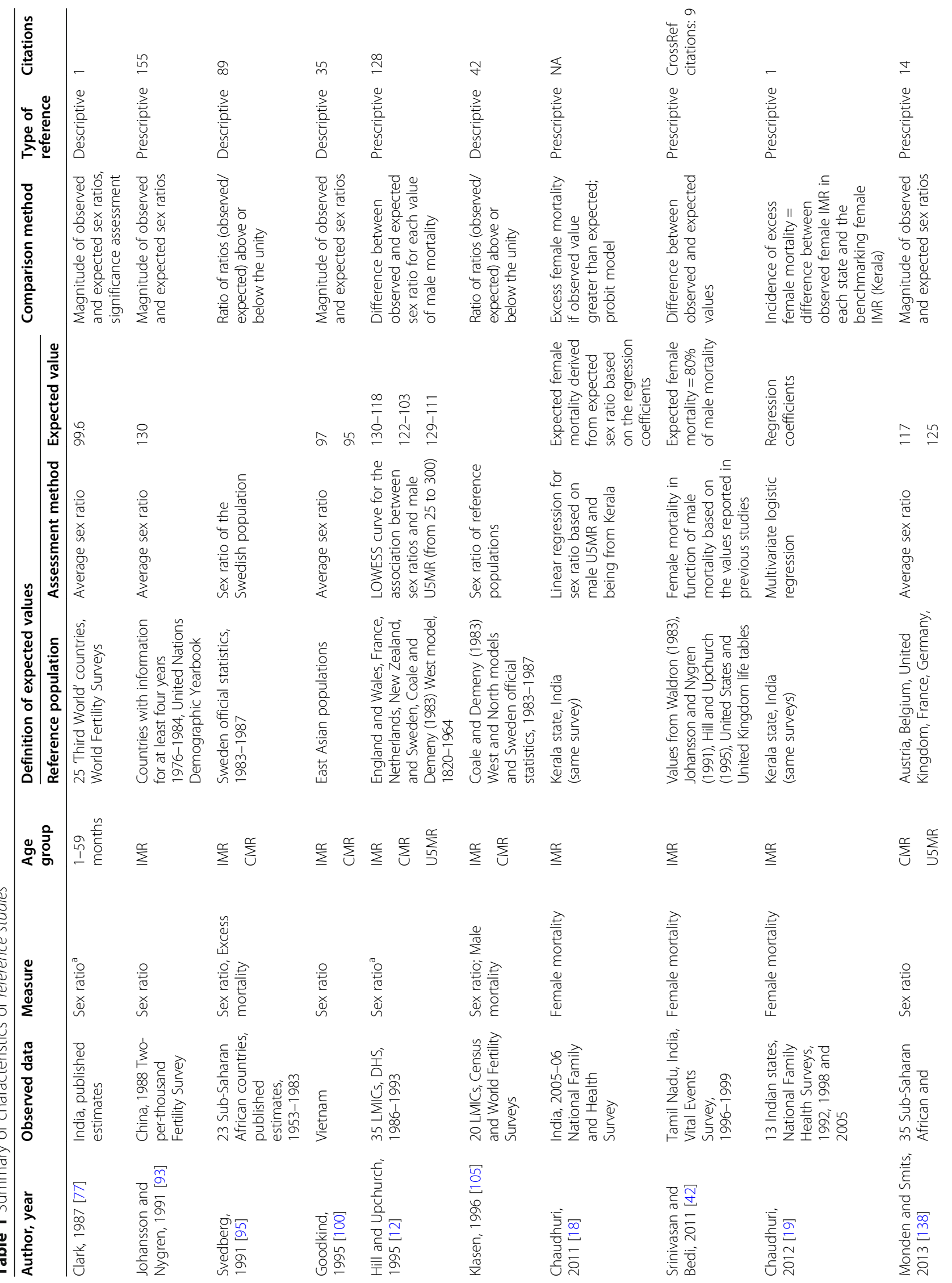


Costa and Victora BMC Pediatrics $\quad$ (2021) 21:55

Page 7 of 17

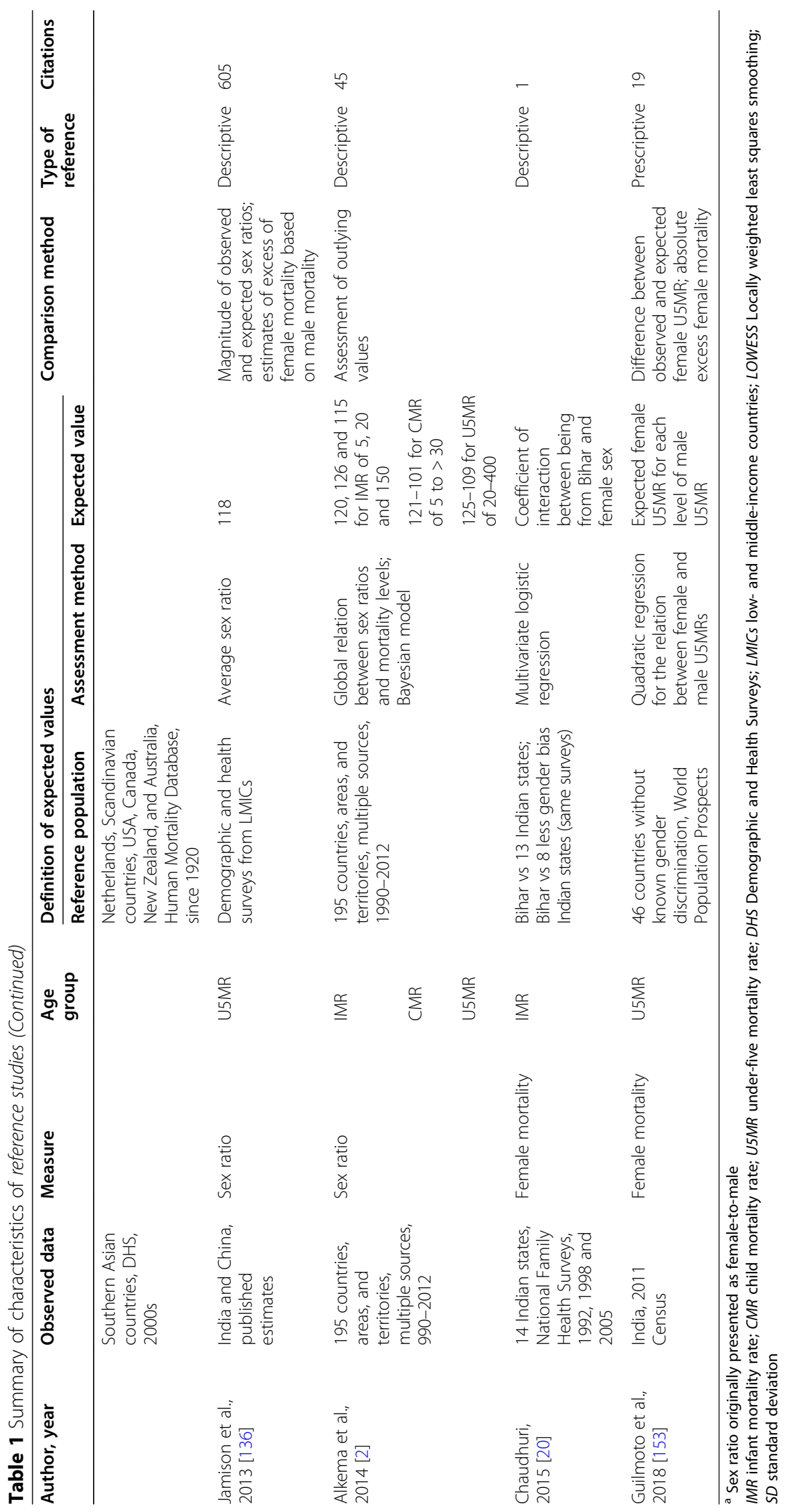


studies. This heterogeneous set of studies relied upon a variety of data sources and analytical methods to define the expected differentials in male and female deaths. The first study was published in the late 1980s [77], five dated from the early 1990 s $[12,93,95,100,105]$, and the other eight from the 2010s $[2,18-20,42,136,138,153]$. A summary of the characteristics is presented in Table 1. For consistency, we recalculated the outcomes and present the actual ratios of male-to-female death rates, even when the authors' presentations were in other formats.

Regarding the age groups under assessment, six studies reported on more than one category, usually IMR, CMR, and U5MR [2, 12, 95, 100, 105, 138], five studies only on IMR [18-20, 42, 93], and three solely on U5MR [77, 136, 153].

Several reference populations were used as the standard against which authors assessed results from one or more countries. The reference populations include: life table models from multiple high-income geographies $[12,95,105,138]$; survey data from LMICs $[18,77,136]$, official statistics gathered by the United Nations [93, 153], estimates published by other authors [42], and multiple sources including census, surveys, vital registration and surveillance systems [2]. Three studies from India used internal comparison parameters, as the authors chose the Kerala state or a set of countries as standards of low gender bias [18-20]. The studies were labeled as prescriptive or descriptive, depending on the judgment of presence or absence of gender bias in the reference populations and this information is presented in Table 1.

In five studies, after the reference population was selected, the average observed sex ratios were calculated and the resulting means were considered as the expected value for a given age group, regardless of the overall mortality level [77, 93, 100, 136, 138]. For example, Johansson and Nygren (1991) proposed an IMR sex ratio of 130 and Jamison et al. (2013) defined a reference of 118 for U5MR sex ratio [93, 136]. Another two studies proposed a range of expected sex ratio values based on overall or male mortality levels $[2,12]$. For example, Hill and Upchurch [12] suggested that for male mortality rates of 25 and 300 per thousand the expected IMR sex ratio should be, respectively 130 and 118 [12]. Lastly, five works presented equations for calculating expected values, usually for female death rates according to levels of male mortality $[18,42,153]$ or for the estimation of sex ratios greater than expected $[95,105]$. Two studies relied upon regression coefficients for comparison $[19,20]$.

While the simpler studies were restricted to calculating average sex ratios as mentioned above, more sophisticated approaches included the use of locally weighted least squares (LOWESS) procedure for the association between sex ratios and male mortality [12], linear, logistic, and quadratic regression models [18-20, 153], a ratio of observed and expected sex ratios [105], and Bayesian models for the association of sex ratios and overall mortality [2].

Most studies compared the reference with observed sex ratios in single Asian countries: seven in India [18-20, 42, $77,136,153]$, two in China $[93,136]$, and one in Vietnam [100]. The remaining studies used data from multiple countries from Sub-Saharan Africa [105, 138], South Asia [138], low- and middle-income countries [12]. Lastly, a global study used data from 195 countries, areas, and territories with available information [2].

To evaluate whether an observed value differed from the reference population, the most frequent procedure was the simple comparison of the magnitudes of the estimates, with only a few studies reporting confidence intervals or other forms of statistical testing [2, 77, 93, 138].

\section{Comparative studies}

The group of 21 comparative studies includes works comparing sex ratios in specific populations to reference values without proposing new methodologies for the definition of expected values. The reference values are either those reflecting the experience of populations in which gender discrimination is supposed to be absent or those from areas, single country, or set of countries for comparison, with no judgment about expected values. Detailed information for each study is presented in Table 2.

The works were published since 1977, mostly from 2000 onwards. The publications reported on sets of countries (Middle East region [47], Arab countries [68], north Africa [97], sub-Saharan Africa [95], low- and middle-income countries [14], or global analyses [127]). The remaining covered one specific country (India [36, 39, 69, 78, 79, 132], China [99, 124], Bangladesh [21, 88, 108], Korea [76], Japan [104], North Korea [113], and Egypt [80]), all from Asia.

The most frequently used references were the Coale and Demeny (1966 and 1983) life tables, which are widely used for estimation and projections [157, 158]. These authors examined a large number of life tables from countries with reliable data, mostly in Europe, and used regression methods to build four families of model life tables, labeled as "West", "North", "East" and "South", corresponding roughly to European regions. The models are based on the observed relationships between mortality in different age ranges and mortality levels. Each model has variants for males and females, which allows the definition of expected levels of mortality by sex or sex ratios, and which may thus be compared to values derived from a given study. Assessments of gender bias were made by comparing observed sex ratios or actual sex- 
Table 2 Summary of characteristics of comparative studies

\begin{tabular}{|c|c|c|c|c|c|c|}
\hline \multirow[t]{2}{*}{ Author, year } & \multirow[t]{2}{*}{ Observed data } & \multirow[t]{2}{*}{ Measure } & \multirow{2}{*}{$\begin{array}{l}\text { Age } \\
\text { group }\end{array}$} & \multicolumn{2}{|c|}{ Definition of comparison parameters } & \multirow[b]{2}{*}{ Comparison method } \\
\hline & & & & Reference population & $\begin{array}{l}\text { Reference value } \\
\text { (when applicable) }\end{array}$ & \\
\hline \multirow{2}{*}{$\begin{array}{l}\text { Hammoud, } \\
1977 \text { [68] }\end{array}$} & \multirow[b]{2}{*}{$\begin{array}{l}\text { Algeria, Democratic } \\
\text { Yemen, Egypt, Iraq, } \\
\text { Jordan, Kuwait, } \\
\text { Libyan Arab } \\
\text { Jamahiriya, Morocco, } \\
\text { Syrian Arab Republic } \\
\text { and Tunisia, multiple } \\
\text { sources, 1951-1974 }\end{array}$} & \multirow[t]{2}{*}{ Sex ratio } & IMR & \multirow[b]{2}{*}{$\begin{array}{l}\text { Mauritius, Canada, Chile, } \\
\text { Mexico, Paraguay, United } \\
\text { States, Hong Kong, Japan, } \\
\text { Philippines, Thailand, } \\
\text { Denmark, Hungary, } \\
\text { Portugal, Yugoslavia, and } \\
\text { Australia (United Nations } \\
\text { and World Health } \\
\text { Organization) }\end{array}$} & \multirow[t]{2}{*}{-} & \multirow{2}{*}{$\begin{array}{l}\text { Magnitude of observed } \\
\text { and expected sex ratios }\end{array}$} \\
\hline & & & CMR & & & \\
\hline \multirow[t]{3}{*}{ Khosla, 1980 [69] } & \multirow{3}{*}{$\begin{array}{l}17 \text { states, India, } \\
\text { Health statistics, } \\
\text { 1971-1975 }\end{array}$} & \multirow[t]{3}{*}{ Sex ratio } & NMR & \multirow{3}{*}{$\begin{array}{l}46 \text { countries from } 1970 \\
\text { to } 1974 \text { (WHO annual } \\
\text { statistics) }\end{array}$} & \multirow[t]{3}{*}{-} & \multirow{3}{*}{$\begin{array}{l}\text { Magnitude of observed } \\
\text { and expected sex ratios }\end{array}$} \\
\hline & & & PNMR & & & \\
\hline & & & IMR & & & \\
\hline \multirow[t]{2}{*}{ Choe, 1987 [76] } & \multirow{2}{*}{$\begin{array}{l}\text { Korea, } 1974 \text { National } \\
\text { Fertility Survey, } \\
\text { 1960-1974 }\end{array}$} & \multirow[t]{2}{*}{ Sex ratio } & IMR & \multirow[b]{2}{*}{$\begin{array}{l}\text { Coale and Demeny (1983) } \\
\text { West and North models, } \\
\text { levels 19, } 20 \text { and } 21 \text { and } \\
\text { life tables for } 10 \text { countries } \\
\text { (Israel, Jordan, Kuwait, } \\
\text { Hong Kong, Sarawak, } \\
\text { Panama, Belize, Jamaica, } \\
\text { Guyana, Portugal) }\end{array}$} & $122-133 ; 81-140$ & \multirow{2}{*}{$\begin{array}{l}\text { Magnitude of observed } \\
\text { and expected sex ratios; } \\
\text { Hazard models for } \\
\text { multivariate analysis }\end{array}$} \\
\hline & & & CMR & & $111-124 ; 71-118$ & \\
\hline $\begin{array}{l}\text { Das Gupta, } \\
1987 \text { [78] }\end{array}$ & $\begin{array}{l}\text { Rural Punjab, India, } \\
\text { Khanna Study, } 1984\end{array}$ & Sex ratio & U5MR & $\begin{array}{l}\text { Khanna } 1957-1959 \text { and } \\
\text { Matlab Thana 1974-1977 }\end{array}$ & - & Magnitude of sex ratios \\
\hline Karkal, 1987 [79] & $\begin{array}{l}\text { India, Sample } \\
\text { Registration System, } \\
\text { 1970-1980 }\end{array}$ & $\begin{array}{l}\text { Sex } \\
\text { difference }\end{array}$ & $\begin{array}{l}0,1,5 \\
\text { years }\end{array}$ & South Asia region & - & $\begin{array}{l}\text { Magnitude of sex-specific } \\
\text { mortality and sex } \\
\text { differences }\end{array}$ \\
\hline $\begin{array}{l}\text { Makinson, } \\
1987[80]\end{array}$ & $\begin{array}{l}\text { Egypt, } 1980 \text { World Fertility } \\
\text { Survey }\end{array}$ & $\begin{array}{l}\text { Female } \\
\text { mortality }\end{array}$ & U5MR ${ }^{\mathrm{a}}$ & $\begin{array}{l}\text { Coale and Demeny (1966) } \\
\text { West model, level } 13.7\end{array}$ & $\begin{array}{l}\text { Observed female } \\
\text { mortality }\end{array}$ & $\begin{array}{l}\text { Magnitude of sex-specific } \\
\text { mortality; multivariable } \\
\text { logistic model }\end{array}$ \\
\hline \multirow{2}{*}{$\begin{array}{l}\text { Chowdhury et al., } \\
1990 \text { [88] }\end{array}$} & \multirow{2}{*}{$\begin{array}{l}\text { Bangladesh, Matlab } \\
\text { Demographic } \\
\text { Surveillance System, } \\
\text { 1977-1985 }\end{array}$} & \multirow{2}{*}{$\begin{array}{l}\text { Female } \\
\text { mortality }\end{array}$} & NMR & \multirow{2}{*}{$\begin{array}{l}\text { Comparison of } 204 \text { sex } \\
\text { discordant twin pairs with } \\
\text { a random sample of } 2371 \\
\text { singletons }\end{array}$} & Odds ratio 98 & \multirow{2}{*}{$\begin{array}{l}\text { Logistic regression and } \\
\text { McNemar's test to assess } \\
\text { sex differences and } \\
\text { conditional survivorship }\end{array}$} \\
\hline & & & IMR & & Odds ratio 140 & \\
\hline $\begin{array}{l}\text { Pebley and Amin, } \\
1991 \text { [39] }\end{array}$ & $\begin{array}{l}26 \text { rural villages in } \\
\text { India, Narangwal } \\
\text { Study }\end{array}$ & Sex ratio & Under- $3^{\mathrm{a}}$ & Study comparison area & - & $\begin{array}{l}\text { Expected mortality rates } \\
1971-1973 \text { without } \\
\text { intervention (control } \\
\text { villages) }\end{array}$ \\
\hline \multirow{2}{*}{$\begin{array}{l}\text { Tabutin, } \\
1992[97]\end{array}$} & \multirow{2}{*}{$\begin{array}{l}\text { Algeria, Morocco, } \\
\text { Tunisia and Egypt, } \\
\text { multiple sources, } \\
\text { 1965-1988 }\end{array}$} & \multirow[t]{2}{*}{ Sex ratio } & IMR & \multirow{2}{*}{$\begin{array}{l}\text { United Nations model life } \\
\text { tables for developing } \\
\text { countries }\end{array}$} & \multirow{2}{*}{$\begin{array}{l}\text { "general pattern" for } \\
\text { the reference countries }\end{array}$} & Magnitude of observed \\
\hline & & & CMR & & & \\
\hline Choe et al., & China, 1988 Two- & Sex ratio & IMR & Coale and Demeny (1983) & $119,123,129$ & Magnitude of sex ratios; \\
\hline & $\begin{array}{l}\text { Survey of Fertility } \\
\text { and Birth Control, } \\
1965-1987\end{array}$ & & CMR & $\begin{array}{l}\text { level 20, and Japan } \\
\text { 1953-1960 }\end{array}$ & $111,113,115$ & $\begin{array}{l}\text { mutivarlate proportional } \\
\text { hazard models }\end{array}$ \\
\hline Clark, 1995 [53] & $\begin{array}{l}\text { Gwembe District, } \\
\text { Zambia, Gwembe } \\
\text { Study, 1956-1992 }\end{array}$ & $\begin{array}{l}\text { Sex-specific } \\
\text { mortality }\end{array}$ & $\mathrm{IMR}$ & Twin pairs and singletons & - & $\begin{array}{l}\text { Comparison of } \\
\text { sex-specific } \\
\text { mortality rates }\end{array}$ \\
\hline Johansson, & Meiji, Japan, & Sex ratio & IMR & Swedish estimates & - & Magnitude of observed \\
\hline & $\begin{array}{l}\text { Published } \\
\text { estimates, } 1908\end{array}$ & & CMR & $\begin{array}{l}\text { (1750-1900), Preston } \\
\text { standard (1976) }\end{array}$ & & \\
\hline $\begin{array}{l}\text { Muhuri and } \\
\text { Menken, } \\
1997 \text { [108] }\end{array}$ & Matlab, Bangladesh & Sex ratio & $\begin{array}{l}1-5 \\
\text { years }\end{array}$ & Study comparison area & - & $\begin{array}{l}\text { Magnitude of sex ratios; } \\
\text { logistic regression }\end{array}$ \\
\hline Goodkind, & North Korea, & Sex ratio & IMR & Previous studies (Makinson & $115-140$ & Magnitude of observed \\
\hline & & & CMR & $\begin{array}{l}\text { 1994; UN 1998); South } \\
\text { Korea, China, and Taiwan }\end{array}$ & $100-120$ & and expected sex ratios \\
\hline $\begin{array}{l}\text { Datta and } \\
\text { Bairagi, } \\
2000[21]\end{array}$ & $\begin{array}{l}\text { Bangladesh, Matlab } \\
\text { Demographic } \\
\text { Surveillance System, }\end{array}$ & Sex ratio & IMR & $\begin{array}{l}\text { Coale and Demeny (1983) } \\
\text { West model and study } \\
\text { comparison area }\end{array}$ & $\begin{array}{l}\text { Excess female mortality } \\
\text { from the equation } \\
\text { [(observed sex ratio) - }\end{array}$ & \\
\hline
\end{tabular}


Table 2 Summary of characteristics of comparative studies (Continued)

\begin{tabular}{|c|c|c|c|c|c|c|}
\hline \multirow[t]{2}{*}{ Author, year } & \multirow[t]{2}{*}{ Observed data } & \multirow[t]{2}{*}{ Measure } & \multirow{2}{*}{$\begin{array}{l}\text { Age } \\
\text { group }\end{array}$} & \multicolumn{2}{|c|}{ Definition of comparison parameters } & \multirow[b]{2}{*}{ Comparison method } \\
\hline & & & & Reference population & $\begin{array}{l}\text { Reference value } \\
\text { (when applicable) }\end{array}$ & \\
\hline & 1977-1995 & & & & $\begin{array}{l}\text { (expected sex ratio)] / } \\
\text { (observed sex ratio)] } \\
(\times 100)\end{array}$ & \\
\hline \multirow[t]{3}{*}{ Yount, 2001 [47] } & \multirow{3}{*}{$\begin{array}{l}14 \text { Middle Eastern } \\
\text { countries, United } \\
\text { Nations, 1970s and } \\
\text { 1980s }\end{array}$} & Sex ratio & IMR & \multirow{3}{*}{$\begin{array}{l}\text { Same datasets for expected } \\
\text { and observed estimates }\end{array}$} & \multirow{3}{*}{$\begin{array}{l}\text { From Hill and Upchurch } \\
\text { (1995) estimated from } \\
\text { the same dataset }\end{array}$} & \multirow{3}{*}{$\begin{array}{l}\text { Magnitude of observed } \\
\text { and expected sex ratios }\end{array}$} \\
\hline & & & CMR & & & \\
\hline & & & U5MR & & & \\
\hline \multirow{3}{*}{$\begin{array}{l}\text { Li et al., } \\
2004 \text { [124] }\end{array}$} & \multirow{3}{*}{$\begin{array}{l}\text { Chinese county in } \\
\text { Shaanxi province, } \\
1997 \text { Household } \\
\text { survey and } \\
\text { community survey }\end{array}$} & \multirow[t]{3}{*}{ Sex ratio } & IMR & \multirow{3}{*}{$\begin{array}{l}\text { Published estimates of sex } \\
\text { ratios from Li and Feldman } \\
\text { (1996); Coale and Demeny } \\
\text { (1983) West model }\end{array}$} & $120-140$ & \multirow{3}{*}{$\begin{array}{l}\text { Magnitude of sex ratios; } \\
\text { likelihood ratio test; } t \text { test } \\
\text { multivariate logistic } \\
\text { regression and Cox } \\
\text { survival }\end{array}$} \\
\hline & & & CMR & & $100-120$ & \\
\hline & & & U5MR & & $>100$ & \\
\hline $\begin{array}{l}\text { Fuse and } \\
\text { Crenshaw, } \\
2006[127]\end{array}$ & $\begin{array}{l}93 \text { countries, United } \\
\text { Nations Statistics } \\
\text { Division, } 2000\end{array}$ & Sex ratio & IMR & $\begin{array}{l}\text { Published estimates } \\
\text { Johansson and Nygren } \\
\text { (1991); Hill and Upchurch } \\
\text { (1995); Tabutin and Willems } \\
\text { (1995) }\end{array}$ & 115 to 130 & Magnitude of sex ratios \\
\hline $\begin{array}{l}\text { Jayaraj, } \\
2009[132]\end{array}$ & $\begin{array}{l}\text { India, Vital } \\
\text { Registration System } \\
\text { (1991 and 2001) and } \\
\text { published estimates }\end{array}$ & $\begin{array}{l}\text { Female } \\
\text { mortality }\end{array}$ & U5MR & $\begin{array}{l}\text { Coale and Demeny (1966) } \\
\text { West model, levels } 18 \\
\text { and } 19\end{array}$ & $\begin{array}{l}\text { Relative survival } \\
\text { advantage of females } \\
\text { (RSASF) }\end{array}$ & $\begin{array}{l}\text { Magnitude of observed } \\
\text { and expected RSAF }\end{array}$ \\
\hline Oster, 2009 [36] & $\begin{array}{l}\text { India, National } \\
\text { Family Health } \\
\text { Surveys, } 1992 \\
\text { and } 1998\end{array}$ & $\begin{array}{l}\text { Female } \\
\text { mortality }\end{array}$ & $\begin{array}{l}\text { Under- } \\
10^{\mathrm{a}}\end{array}$ & $\begin{array}{l}\text { Ethiopia, Kenya, Malawi, } \\
\text { Namibia, Tanzania, and } \\
\text { Zambia, DHS, 1992-2001 }\end{array}$ & $\begin{array}{l}\text { Regression coefficients, } \\
\text { allowing for the } \\
\text { interaction between } \\
\text { being from India and } \\
\text { female sex }\end{array}$ & Difference-in-differences \\
\hline $\begin{array}{l}\text { Costa et al., } \\
2017[14]\end{array}$ & $\begin{array}{l}60 \text { LMICs, DHS, } \\
2005-2014\end{array}$ & $\begin{array}{l}\text { Female } \\
\text { mortality }\end{array}$ & U5MR & $\begin{array}{l}\text { Same DHS datasets for } \\
\text { expected and observed } \\
\text { estimates }\end{array}$ & $\begin{array}{l}\text { From Hill and Upchurch } \\
\text { (1995) and Alkema et al. } \\
\text { (2014) estimated from } \\
\text { the same dataset }\end{array}$ & $\begin{array}{l}\text { Excess female mortality } \\
(\%)=\text { observed/ expected }\end{array}$ \\
\hline
\end{tabular}

${ }^{a}$ Specific subgroups of age (refer to Supplementary Table S2)

IMR infant mortality rate; CMR child mortality rate; USMR under-five mortality rate; DHS Demographic and Health Surveys; LMICS low- and middle-income countries

specific mortality levels with expected values according to the model life tables [21, 76, 80, 99, 124, 132].

The Hill and Upchurch (1995) and the Alkema et al. (2014) references, described above, were also used in some studies, alone or combined with other methods $[14,47]$. Both provide parameters that allow estimating expected sex ratios for a given level of male or overall mortality.

Intervention studies often compare their results with a control area [39, 78, 108]. Other parameters included mortality by sex in high-income countries such as Sweden [95, 104, 105] and Japan [99], sets of countries $[36,68,69,79]$, previously published expected values from other works $[113,124,127]$, and singleton births as reference for sex-discordant pairs of twins [88].

\section{Narrative studies}

The remaining 119 publications were categorized as narrative as they assessed sex differentials in childhood mortality, but do not rely on any reference or expected value to corroborate the presence of bias. The assessed outcomes include absolute differences in male and female rates, sex ratios calculated either by dividing the observed sex-specific rates or derived from statistical models (as odds ratio, hazard ratio, relative risk.). This group includes studies that either did not perform statistical tests to compare rates by sex or, if these tests were included, did not account for the greater biological weakness of male children. Nonetheless, studies with higher mortality among girls are useful because this should not occur unless there is some degree of bias against girls. Also, in this group are the studies that used multivariable analyses, including sex as one of the predictors, or sex-specific models.

Up to the late 1970s, all publications used narrative approaches, mostly reporting on time series, with a historical perspective on mortality sex ratios $[15,27,51,54$, 56, 57, 61, 63-67]. Almost all studies conducted with populations from high-income geographies, e.g. Belgium [4, 22], Canada [64], England [7, 30, 56], Japan [66, 114], The Netherlands [5], Sweden [118, 144], Taiwan [35], and United States $[17,51,57,65,84,135,152]$ are in 
this group, as well as sets of high-income countries $[15,61,122]$. The approaches used in each study can be found in Supplementary Table S2.

\section{Discussion}

In this review, we described 154 studies published since 1929 that employed quantitative methods to address sex differentials in early childhood mortality. The main challenge in these analyses is how to separate biologically determined sex differences from gender inequities that may affect mortality rates.

The studies included in our review reflect the evolution of knowledge over time across world regions. The early literature (up to the 1980s) is predominantly from high-income countries and aimed at the simple description of sex differentials. These studies established higher mortality among boys and explored potential biological mechanisms for such differences. Parameters derived from such early studies were then used in more recent years to identify populations where girls were more likely to die than would be expected. Both types of studies are relevant because early research was essential for interpreting recent findings.

Biological reasons for the lower mortality among girls include, for instance, the presence of two copies of the $\mathrm{X}$ chromosome, whereas male individuals have only one. The $\mathrm{X}$ chromosome carries more than a thousand genes and many of them are responsible for immune response, fetal development, and metabolic functions [9]. Additionally, higher odds of congenital abnormalities, lower five-minute Apgar score, need for assistant ventilation, respiratory distress syndrome in the male than in female children are some examples of male frailty [10].

Given the biological disadvantage of male children, usually, gender bias is suspected when the mortality of girls is higher than expected, which may be due to the cultural favoritism of male children resulting in neglect of girls. Although such culturally-driven 'son preference' is likely the main reason for higher-than-expected mortality of girls, infanticide may also affect sex ratios, although it seems to be restricted to a few societies $[43,52]$; the frequency of infanticide, however, is extremely hard to measure. Whatever the reason, bias against girls is likely to affect the sex ratios, leading to either similar mortality rates for both sexes or higher mortality for girls than for boys [43, 159, 160].

Specifically, the complexities in the analyses include the specification of expected values for sex ratios for a given mortality level, the definition of what constitutes excess mortality of girls or boys, and the availability and quality of the data. In light of these conundrums, selected publications were grouped according to the methodological approach.
Fourteen studies (about 9\%) aimed at presenting reference parameters, as well as analytical methods to define the expected relationship between male and female mortality. These publications are quite heterogeneous and rely either on the comparison of populations with similar mortality levels or on historical data from currently high-income populations. The most influential articles in this group include the standard developed by Hill and Upchurch (1995) based on the historical experience of high-income populations and the reference by Alkema et al. (2014) based on recent data from 195 countries $[2,12]$. Besides, no statistical testing was performed in some studies, and any magnitude of differences between observed and expected values was considered. For these publications, the comparison with populations with different demographic characteristics arises as an additional limitation.

We have classified reference studies as either descriptive or prescriptive. A previous analysis employed two of the reference methods included in this review in a set of surveys from LMICs to compare their potential for identifying countries with evidence of gender bias in U5MR [14]. The authors found higher values of excess female mortality when using the expected values from Hill and Upchurch [12], a prescriptive approach, than when using Alkema et al. [2] estimates, a descriptive method [74].

Twenty-one publications (14\%) were comparative studies that used either external or internal comparison parameters. The comparisons used in analyses included parameters defined by reference studies mentioned above, for example, the Hill and Upchurch standards. Other studies relied on Coale and Demeny's life table models (1966 and 1983) [157, 158]. Even though these tables were not originally proposed for comparing mortality sex ratios - and therefore were not included in the group of reference studies summarized above - they have been widely used to define expected values. The limitation that arises in these situations is that model life tables incorporate estimates of typical sex differences in mortality for different levels of life expectancy for European populations, rather than for levels of child mortality [12]. Additionally, the estimates differ both according to the model and according to the level within each model [77]. It should be noted that present-day LMICs - the principal focus of the analyses - may have epidemiological and demographic profiles that differ from the settings upon which the models used as the reference were based. Additionally, the definition of the comparison group is often based on a priori, arbitrary judgment of absence of gender discrimination. Even so, these comparisons are useful for monitoring sex ratios and identifying outliers. Some studies combined values from published sex ratios in different populations to define expected values, which is questionable. 
Most studies classified in the narrative group were restricted to describing sex ratios within a population, without comparisons to a reference or standard to interpret these results. Typically, sex ratios above or below the unity are assumed to be indicative of excess mortality for boys or girls. These studies are useful for providing an overview of the relationship between male and female mortality, especially in time series. Their main limitations include failing to account for the biological frailty of boys, lack of adjustment for overall mortality level, and absence of statistical assessment of the sex differences. Even so, more than identifying statistical differences between male and female mortality, it would be necessary to analyze if the relationship between the estimates is different from that that would be expected in a given context. Unless a study shows significantly higher mortality of girls than boys, which is never observed in the absence of gender bias, in general, these studies are not robust enough to provide evidence of discrimination.

Other characteristics of the publications identified in the review are discussed below. Different age ranges for mortality were used in the studies. It is important to highlight that neonatal mortality is heavily influenced by biological factors, being less sensitive to familial behavior. Post-neonatal mortality is more likely to be independent of preexisting medical complications and to happen at home, and more dependent on nurturing care provided by the family. Beyond the age of one year, the female mortality advantage is not marked as is the case for infants, and the effects of discrimination become more evident [1]. Nonetheless, there are many biomedical interventions, such as antibiotics or vaccines, that may prevent infant deaths, and for which access may be affected by gender bias in care-seeking behaviors [161].

In terms of the populations under study, most analyses came out of India, a country known for gender discrimination against females and where various interventions have been used to prevent what has been described as "daughter elimination" [43]. India, Bangladesh, and China were explored in almost half of all studies. In these three countries, there is vast evidence of female disadvantage in survival, regardless of the method used to assess it. Interestingly, few standalone studies were based on other South Asian or Middle Eastern countries, which multi-country studies often single out as presenting gender bias. Works that used data from high-income countries were mainly published up to 1980 , all of them were included in the narrative group of studies. Most of these studies were focused on the magnitude of male disadvantage in survival. In the few studies reporting higher mortality among girls, this was only observed beyond the childhood period, particularly during adolescence or adulthood, being related to maternal deaths or those associated with the occupation.

Regarding data sources, civil or vital registration systems are the gold standard, as these record births and deaths on a continuous real-time basis and cover a whole defined population. However, few LMICs have such systems in place with sufficient coverage and quality. Therefore, household surveys collecting information on reproductive histories of women, including births and deaths of their children, constitute the main source of nationally representative child mortality estimates for LMICs. However, they may present some limitations. Since they are based on retrospective self-reports, there is always a chance that the number and sex of children have been misreported. Also, there may be errors in the dating of events and age heaping, the omission of events, and sampling errors. The same limitations apply to census data, which are also frequently used for mortality estimation using indirect methods. Waldron (1983) compared mortality sex ratios estimated from the United Nations life tables (based on vital registration) and from the World Fertility Surveys for 17 countries and found a weak correlation between these estimates, with girls presenting $12 \%$ higher mortality than boys in the WFS data, while this difference was only $5 \%$ in the life tables data for an overlapping 10-year period [8]. As mentioned above, a limitation of all data sources is that they do not allow a direct assessment of female infanticide, which would be very important for identifying gender discrimination.

The reasons behind son preference and daughter neglect vary from society to society. In some countries, the need to pay dowries for marrying daughters may impact in family's economies, whereas in other cultures, son preference is attributed more to patriarchal systems and low female autonomy [162]. Also, religious roles that can only be performed by men may lead to the family's preference for male children [163]. Cultural characteristics and societal values sometimes combine with limitations of resources, which leads families to choose internally which children will benefit [162, 163].

Yet, higher-than-expected male mortality could imply that boys experience mortality to a degree disproportionate to their biological disadvantage. Some evidence is provided by historical changes in sex ratios in highincome countries [11]. This study revealed that the decline in infectious diseases and the relative increase in perinatal causes led male-to-female ratios in infant mortality to increase, after which the improvement of obstetric and neonatal care led to a subsequent decline in the sex ratio [11].

We also noticed a lack of standardization in data aggregation levels. The use of national data, for example, 
may be problematic as they do not account for subnational variability in household and family characteristics, including behaviors influenced by son-biased values, for instance. Studies from India document important differences among the Northern and Southern states, with less evidence of gender bias in the latter [18-20,153].

Studies assessing multiple countries often used data sources covering different periods or failing to study a representative sample of a given world region. Studies of time trends will be more informative than those reporting on single points in time, as sex ratios may vary as a function of historical elements such as war mortality, fertility transitions, and famines.

A related issue, addressed in some articles, is evidence that reductions in excess female mortality observed might be related to increasing pre-natal sex selection practices, supporting the hypothesis that infanticide and neglect of girls are being replaced by sex-selective abortion of female fetuses, contributing to the 'missing women' phenomenon.

Some authors argue that population sex ratios would be a more appropriate measure to assess gender bias given that these combine pre- and post-natal discrimination and account for sex-selective migration [82]. Population sex ratios were not covered in this review since we were interested primarily in methods for mortality analyses and assessment of the impact on liveborn children. Nonetheless, a few studies included in this review combined assessments of gender bias in mortality (the so-called 'post-natal female deficit') and prenatal sex selection [19, 29, 42, 43, 78].

The investigation of factors associated with sex ratios falls outside of the scope of the present work, but it is noteworthy that many studies complemented their survival analyses with the assessment of potential determinants including health care behaviors [14, 24, 112], health status [82], socioeconomic characteristics [31, 47, $84,85,90,98,111,126]$, family composition $[76,99,109$, $110,123,148]$, fertility choices and differential stopping behavior $[20,107,126,141,148]$. Also, the societal position and value of girls and women, including education, power, autonomy, control over resources, and economic and social status, may affect their survival probabilities [83].

The discussion about sex differences in mortality goes beyond childhood and from a lifetime perspective, we point out the debate concerning differentials in life expectancy for males and females and the data sources and methodologies that have been a topic of discussion among researchers $[164,165]$.

The authors of the studies under review call for further investigation on the causes of unexpected sex differentials and the introduction of more systematic monitoring of sex differences in child mortality.
Qualitative research is also necessary to document the unfair distribution of resources and discriminatory treatment of boys and girls. The mechanisms of gender discrimination are complex and multilayered, ranging from deliberate neglect in health-seeking behaviors to bias in resource allocation, which is difficult to assess solely through quantitative analyses. Moreover, additional research is needed to understand the national and regional differences in the economic and societal roles of girls and women, which seems to affect female survival.

Some caveats in the review process must be recognized. As scoping reviews do not assess study quality, some of the literature reviewed may be methodologically flawed. Also, the screening process and data extraction were not performed in duplicate. Nevertheless, our work fills a gap in the literature by summarizing studies carried out over a long-time span, and by contributing to the understanding of analyses on sex differentials in childhood mortality. The main strength of our review is the use of comprehensive combinations of terms for building the search strategy, which produced a list of about 17,000 studies to be screened. Through this search, we were able to identify the huge diversity of journals in distinct fields - such as Epidemiology, Demography, and Economics - that have published on this topic, documenting that gender and survival issues affect multiple aspects of global well-being. Additionally, the visual representation of the words used in the titles of the works reveals the diversity of terminologies, which has presented an extra challenge for the review screening process.

Rather than comparing results that emerged from analyses performed with multiple methods, our review focused on the discussion of methodological approaches for identifying gender bias and addressed the need for standardization of methodologies.

In summary, much effort has been made to measure, interpret, and explain sex differentials in early childhood mortality. Over time, there have been advances regarding data availability and quality, and in the sophistication of statistical methods on the relationship between male and female mortality, allowing definitions of what would be the so-called 'normal' and in the identification of unexpected differences. Yet, many authors still fail to account for the role of mortality levels in contributing to sex ratios. The issue of what constitutes the expected values of sex ratios for a given level of mortality is still open to debate but the use of model life tables and historical time series still have a role to play.

To overcome the limitations, future research on this topic should account for overall mortality levels, address different groups of age at death, and account for causes of deaths whenever possible. We also suggest the use of more than one reference value to allow interpretation of 
findings in light of different parameters, and the use of formal statistical testing that account for the variability of estimates of sex ratios.

\section{Conclusion}

Addressing factors possibly associated with the sex differentials and the mechanisms underlying the biased estimates is also crucial and should cover distal as well as proximal factors. Time trends analyses, performed with a consistent methodology, can help understand both the sex differentials in a historical perspective and their relationship with changes in development level, improvements in health care, and advances in the gendered nature of social norms.

The results presented here underscore the need for further work on how to identify appropriate references for evaluating sex differentials on child mortality, leading to the formulation of policy interventions aimed at closing the unfair gender gap in childhood survival. Finally, we reinforce the call of Sustainable Development Goal 17.18 for disaggregation of data to identify more vulnerable groups within countries.

\section{Supplementary Information}

The online version contains supplementary material available at https://doi. org/10.1186/s12887-021-02503-8.

Additional file 1: Table S1. PRISMA checklist. Table S2. Summary of characteristics of all 154 studies included in the review. Figure S1. Frequency of words used in the titles of the selected studies.

\section{Abbreviations}

CMR: Child mortality rate; DHS: Demographic and Health Survey; IMR: Infant mortality rate; LMICs: Low- and middle-income countries; LOWESS: Locally weighted least squares; NMR: Neonatal mortality rate; PNMR: Post-neonatal mortality rate; SD: Standard deviation; U5MR: Under-five mortality rate; WFS: World Fertility Survey

\section{Acknowledgments}

Not applicable.

\section{Authors' contributions}

JCC conducted the search and data extraction; JCC and CGV contributed to the design of the research, to the analysis of the results, and to the writing of the manuscript. All authors have read and approved the manuscript.

\section{Funding}

This work was supported by the Bill and Melinda Gates Foundation [grant number OPP1199234], The Wellcome Trust [grant number 101815/Z/13/Z], Brazilian National Council for Scientific and Technological Development, Coordination of Superior Level Staff Improvement, and the Brazilian Association of Collective Health. The funding sources had no role in study design, data collection, data analysis, data interpretation, or writing of the manuscript.

\section{Availability of data and materials}

Not applicable.

\section{Ethics approval and consent to participate}

This review was exempted from ethics review as the data used have already been published.

\section{Consent for publication}

Not applicable.

\section{Competing interests}

The authors declare no competing interests.

Received: 4 October 2020 Accepted: 12 January 2021

Published online: 26 January 2021

\section{References}

1. United Nations, Department of Economic and Social Affairs, Population Division. Sex differentials in childhood mortality. New York 2011.

2. Alkema L, Chao F, You D, Pedersen J, Sawyer CC. National, regional, and global sex ratios of infant, child, and under-5 mortality and identification of countries with outlying ratios: a systematic assessment. Lancet Glob Health. 2014;2(9):e521-e30.

3. United Nations Secretariat. Levels and trends of sex differentials in infant, child, and under-five mortality. In: Nations $U$, editor. Too young to die: genes or gender? New York: United Nations; 1998.

4. Eggerickx T, Tabutin D. La surmortalité des filles vers 1890 en Belgique: Une approche régionale. Population (French Edition). 1994;49(3):657-83.

5. Janssens A, Messelink M, Need A. Faulty genes or faulty parents? Gender, family and survival in early and late childhood in the Netherlands, 18601900. History Family. 2010;15(1):91-108.

6. Tabutin D, Willems M. Differential mortality by sex from birth to adolescence: this historical experience of the west (1750-1930). In: United Nations, editor. Too young to die: genes or gender? New York: United Nations; 1998.

7. McNay K, Humphries J, Klasen S. Excess female mortality in nineteenthcentury England and Wales - a regional analysis. Soc Sci Hist. 2005;29(4): 649-81.

8. Waldron I. Patterns and causes of excess female mortality among children in developing countries. World Health Stat Q. 1987;40(3):194-210.

9. Migeon BR. Why females are mosaics, $x$-chromosome inactivation, and sex differences in disease. Gender Med. 2007;4(2):97-105.

10. Zhao D, Zou L, Lei $X$, Zhang Y. Gender differences in infant mortality and neonatal morbidity in mixed-gender twins. Sci Rep. 2017;7(1):8736.

11. Drevenstedt GL, Crimmins EM, Vasunilashorn S, Finch CE. The rise and fall of excess male infant mortality. Proc Natl Acad Sci U S A. 2008;105(13):5016-21.

12. Hill K, Upchurch DM. Gender differences in child health - evidence from the demographic and health surveys. Popul Dev Rev. 1995;21(1):127-51.

13. Sawyer CC. Child Mortality Estimation: Estimating Sex Differences in Childhood Mortality since the 1970s. PLoS Med. 2012;9(8).

14. Costa JC, da Silva ICM, Victora CG. Gender bias in under-five mortality in low/middle-income countries. BMJ Glob Health. 2017;2(2):e000350.

15. Abramowicz M, Barnett HL. Sex ratio of infant mortality. Am J Dis Children. 1970;119(4):314-5.

16. Attane I. The determinants of discrimination against daughters in China: evidence from a provincial-level analysis. Popul Stud. 2009;63(1):87-102.

17. Bhaumik U, Aitken I, Kawachi I, Ringer S, Orav J, Lieberman E. Narrowing of sex differences in infant mortality in Massachusetts. J Perinatol: official journal of the California Perinatal Association. 2004;24(2):94-9.

18. Chaudhuri S. Does gender discrimination contribute to India's population imbalance? A household level analysis. Int J Econ Policy Emerg Econ. 2011; 4(4):390-406.

19. Chaudhuri S. Female infant mortality disadvantage in India: a regional analysis. Review Rad Political Econ. 2012;44(3):321-6.

20. Chaudhuri S. Excess female infant mortality and the gender gap in infant care in Bihar, India. Feminist Economics. 2015;21(2):131-61.

21. Datta AK, Bairagi R. Improvement in female survival: a quiet revolution in Bangladesh. Asia-Pac Popul J. 2000;15(1):19-40.

22. Devos I. La régionalisation de la surmortalité des jeunes filles en Belgique entre 1890 et 1910 [Regionalization of the total mortality of young girls in Belgium between 1890 and 1910]. Ann Demogr Hist (Paris). 1996:375-407.

23. D'Souza S, Chen LC. Sex differentials in mortality in rural Bangladesh. Population Dev Rev. 1980;6(2):257-70.

24. Mbacke C, LeGrand T. Differences de mortalité selon le sexe et utilisation des services de santé au Mali. Cahiers quebecois de demographie. 1992; 21(1):99-119.

25. Narayana D. Intensifying infant mortality inequality in India and a reversal by policy intervention. J Hum Dev. 2008;9(2):265-81.

26. Agnihotri AK. Declining infant and child mortality in India: how do girl children fare? Econ Polit Wkly. 2001;36(3):6. 
27. El-Badry MA. Higher female than male mortality in some countries of South Asia: a digest. J Am Stat Assoc. 1969;64(328):1234-44.

28. Finlay R. Differential child mortality in pre-industrial England: the example of Cartmel, Cumbria, 1600-1750. Annales de demographie historique; 1981. p. 67-80.

29. Gellatly C, Petrie M. Prenatal sex selection and female infant mortality are more common in India after firstborn and second-born daughters. J Epidemiol Community Health. 2017;71(3):269-74.

30. Humphrey L, Bello S, Rousham E. Sex differences in infant mortality in Spitafields, London, 1750-1839. J Biosoc Sci. 2012;44(1):95-119.

31. Karlsson O, Kim R, Joe W, Subramanian SV. Socioeconomic and gender inequalities in neonatal, postneonatal and child mortality in India: a repeated cross-sectional study, 2005-2016. J Epidemiol Community Health. 2019;73(7):660-7.

32. Krishnan A, Nawi NG, Byass P, Pandav CS, Kapoor SK. Sex-specific trends in under-five mortality in rural Ballabgarh. Indian Pediatr. 2014;51(1):48-51.

33. Langford C, Storey P. Sex differentials in mortality early in the 20th century Sri Lanka and India compared. Popul Dev Rev. 1993;19(2):263-82.

34. Langford CM. Sex differentials in mortality in Sri Lanka: changes since the 1920s. J Biosoc Sci. 1984;16(3):399-410.

35. Lin MJ, Liu JT, Qian N. More missing women, fewer dying girls: the impact of sex-selective abortion on sex at birth and relative female mortality in Taiwan. J Eur Econ Assoc. 2014;12(4):899-926.

36. Oster E. Proximate sources of population sex imbalance in India. Demography. 2009;46(2):325-39.

37. Park H, Han S, Kye B. Changes in child mortality in Korea during the midtwentieth century: gender, birth order and sibling composition. History Fam. 2018;23(4):594-622.

38. Patra N. Inter-temporal pattern of gender bias in infant mortality in India: evidence from NFHS and SRS. Int J Child Adolesc Health. 2011;4(1):53-65.

39. Pebley A, Amin S. The impact of a public-health intervention on sex differentials in childhood mortality in rural Punjab. Health Transit Rev. 1991; 1(2):143-69.

40. Raj A, Johns NE, McDougal L, Trivedi A, Bharadwaj P, Silverman JG, et al. Associations between sex composition of older siblings and infant mortality in India from 1992 to 2016. EClinicalMedicine. 2019;14:14-22.

41. Srinivasan S, Bedi AS. Daughter elimination in Tamil Nadu, India: a tale of two ratios. J Dev Stud. 2008;44(7):961-90.

42. Srinivasan S, Bedi AS. Ensuring daughter survival in Tamil Nadu, India. Oxford Dev Stud. 2011;39(3):253-83.

43. Sudha S, Irudaya RS. Female demographic disadvantage in India 1981-1991: sex selective abortions and female infanticide. Dev Change. 1999;30(3):585-618.

44. Tabutin D, Willems M. Excess female child mortality in the developing world during the 1970s and 1980s. Popul Bull UN. 1995;39:45-78.

45. Tarozzi A. Some facts about boy versus girl health indicators in India: 19922005. CESifo Economic Studies. 2012;58(2):296-321.

46. Xu BH, Rimpela A, Jarvelin MR, Nieminen M. Sex-differences of infant and child mortality in China. Scand J Soc Med. 1994;22(4):242-8.

47. Yount KM. Excess mortality of girls in the Middle East in the 1970s and 1980s: patterns, correlates and gaps in research. Popul Stud (Camb). 2001; 55(3):291-308.

48. Yount KM, Zureick-Brown S, Halim N, LaVilla K. Fertility decline, Girls' wellbeing, and gender gaps in Children's well-being in poor countries. Demography. 2014;51(2):535-61.

49. Alam N, Bairagi R. Does a health project reduce excess female child mortality in a son-preferring society? In: Khlat M, editor. Demographic evaluation of health Programmes. Paris: Committee for International Cooperation in National Research in Demography; 1997. p. 205-21.

50. Arokiasamy P. Sex ratio at birth and excess female child mortality in India: trends, differentials and regional patterns. In: Attané I, Guilmoto C, editors. Watering the neighbour's garden: the growing demographic female deficit in Asia. Paris: Committee for International Cooperation in National Research in Demography; 2007. p. 49-72.

51. Bakwin H. The sex factor in infant mortality. Hum Biol. 1929;1(1):90-116.

52. Chunkath S, Athreya V. Female infanticide in Tamil Nadu: Some evidence. Econ Polit Wkly. 1997;32(17):WS21-WS8.

53. Clark S, Colson E, Lee J, Schudder T. Ten thousand Tonga: a longitudinal anthropological study from southern Zambia, 1956-1991. Popul Stud. 1995; 49(1):91-109.

54. Holmes $S$, Mentzer $V$. Changes in the sex ratio in infant mortality according to age. Hum Biol. 1931;3(4):560-75.
55. Kuntla S, Goli S, Jain K. Explaining sex differentials in child mortality in India: trends and determinants. Int J Population Res. 2014;2014:1-7.

56. Martin W. A comparison of the trends of male and female mortality. J R Stat Soc A. 1951;114(3):287-306.

57. McMillen M. Differential mortality by sex in fetal and neonatal deaths. Science. 1979;204(4388):89-91.

58. Nadarajah T. The transition from higher femaleto higher male mortality in Sri Lanka. Popul Dev Rev. 1983;9(2):317-25.

59. Padmanabha P. Mortality in India: a note on trends and implications. Econ Polit Wkly. 1982;17(32):1285-90.

60. Sudha S, Rajan S. Persistent daughter disadvantage: what do estimated sex ratios at birth and sex ratios of child mortality risk reveal? Econ Polit Wkly. 2003;38(41):4361-9.

61. Tabutin D. La surmortalité féminine en Europe avant 1940. Population (French Edition). 1978;33(1):121-48.

62. Tabutin D, Gourbin C, Beninguisse G. Surmortalité et santé des petites fille em Afrique. Tendance des années 1970 aux années 1990. Colloque international Genre, population et développement en Afrique; 2001

63. Teitelbaum M. Male and female components of perinatal mortality: international trends, 1901-1963. Demography. 1971;8(4):541-8.

64. Wyllie J. Sex differences in infant mortality. Canadian Public Health J. 1933; 24(4):177-85.

65. Shapiro S. Influence of birth weight, sex, and plurality on neonatal loss in the United States, vol. 44; 1954. p. 1142-53.

66. Takahashi E. The sex ratio of nenonatal deaths in Japan. Hum Biol. 1954; 26(2):133-42.

67. Hammoud E. Studies in fetal and infant mortality. II. Differentials in mortality by sex and race. Am J Public Health Nat Health. 1965;55(8):1152-63.

68. Hammoud El. Sex differentials in mortality. An enquiry with reference to the Arab countries and others. World Health Stat Quarterly. 1977;30(3):174-206.

69. Khosla T. The plight of female infants in India. J Epidemiol Community Health. 1980;34:143-6.

70. Langsten $\mathrm{R}$. The effect of crises on differential mortality by sex in Bangladesh. Bangladesh Dev Stud. 1981;9(2):75-96.

71. Rosenzweig M, Schultz T. Market opportunities, genetic endowments and intrafamily resources distribution: child survival in rural India. Am Econ Rev. 1982;72(4):803-15.

72. Rutstein S. Infant and child mortality: levels, trends and demographic differentials. Voorburg: International Statistical Institute; 1984.

73. Sabir NI, Ebrahim GJ. Are daughters more at risk than sons in some societies? J Trop Pediatr. 1984;30(4):237-9.

74. Koenig MA, Dsouza S. Sex-differences in childhood mortality in rural Bangladesh. Soc Sci Med. 1986;22(1):15-22.

75. Berman SM, Binkin NJ, Hogue CJR. Assessing sex differences in neonatal survival: a study of discordant twins. Int J Epidemiol. 1987;16(3):436-40.

76. Choe MK. Sex differentials in infant and child mortality in Korea. Soc Biol. 1987;34(1-2):12-25.

77. Clark AW. Social demography of excess female mortality in India - new directions. Econ Polit Wkly. 1987;22(17):WS12-21.

78. Das GM. Selective discrimination against female children in rural Punjab, India. Population Dev Rev. 1987;13(1):77-100.

79. Karkal M. Differentials in mortality by sex. Econ Polit Wkly. 1987;22(32): 1343-7.

80. Makinson C. Sex differentials in infant and child mortality in Egypt. Population Index. 1987;53(3):411.

81. Sathar ZA. Sex differentials in mortality: a corollary of son preference? Pakistan Dev Rev. 1987;26(4):555-68.

82. Basu AM. Is discrimination in food really necessary for explaining sex differentials in childhood mortality? Popul Stud. 1989;43(2):193-210.

83. Kumar G. Gender, differential mortality and development: the experience of Kerala. Cambridge J Econ. 1989;13(4):517-39.

84. Abernethy $V$, Yip R. Parent characteristics and sex differential infant mortality: the case in Tennessee. Hum Biol. 1990;62(2):279-90.

85. Ahmed FA. Gender difference in child mortality. Egyptian Population Fam Plan Rev. 1990;24(2):60-79.

86. Amin S. The effect of women's status on sex differentials in infant and child mortality in South Asia. Genus. 1990:46(3-4):55-69.

87. Caldwell P, Caldwell J. Gender implications for survival in South Asia. Canberra: National Centre for Epidemiology and Population Health, Australian National University; 1990. 
88. Chowdhury MK, Khan NU, Wai L, Bairagi R. Sex differences and sustained excess in mortality among discordant twins in Matlab, Bangladesh: 19771985. Int J Epidemiol. 1990;19(2):387-90.

89. Bhuiya A, Streatfield K. Mothers' education and survival of female children in a rural area of Bangladesh. Popul Stud. 1991;45(2):253-64.

90. Bourne KL, Walker GM. The differential effect of mothers education on mortality of boys and girls in India. Population Stud. 1991;45(2):203-19.

91. Fauveau V, Koenig MA, Wojtyniak B. Excess female deaths among rural bangladeshi children: an examination of cause-specific mortality and morbidity. Int J Epidemiol. 1991;20(3):729-35.

92. Harpending HC, Pennington R. Age structure and sex-biased mortality among Herero pastoralists. Hum Biol. 1991;63(3):329-53.

93. Johansson S, Nygren O. The missing girls of China: a new demographic account. Population Deve Rev. 1991;17(1):35-51.

94. Muhuri P, Preston S. Effects of family composition on mortality differentials by sex among children in Matlab, Bangladesh. Population Dev Rev. 1991; 17(3):415-34.

95. Svedberg P. Undernutrition in sub-Saharan Africa: is there a gender bias? J Dev Stud. 1991;26(3):469-86.

96. Arnold F. Sex preference and its demographic and health implications. Int Fam Plan Perspect. 1992;18(3):93-101.

97. Tabutin D. Excess female mortality in northern Africa since 1965: a description. Population. 1992;4:187-207.

98. Kishor S. May god give sons to all': gender and child mortality in India. Am Sociol Rev. 1993;58(2):247-65.

99. Choe MK, Hao H, Wang F. Effects of gender, birth order, and other correlates on childhood mortality in China. Soc Biol. 1995;42(1-2):50-64.

100. Goodkind D. Rising gender inequality in Vietnam since reunification. Pacific Affairs. 1995;68(3):342.

101. Legrand TK, Mbacke CS. Sex differences in mortality among young children in the Sahel. Population Bull U N. 1995;39:79-111.

102. Murthi M, Guio AC, Dreze J. Mortality, fertility, and gender bias in India: a district-level analysis. Population Dev Rev. 1995;21(4):745-82.

103. Ren XS. Sex differences in infant and child mortality in three provinces in China. Soc Sci Med. 1995;40(9):1259-69.

104. Johansson SR. In: Digby A, Stewart J, editors. Excess female mortality constructing survival during development in Meiji Japan and Victorian England; 1996. p. 32-66.

105. Klasen S. Nutrition, health and mortality in sub-Saharan Africa: is there a gender bias? J Dev Stud. 1996;32(6):913-32.

106. Arnold F. Gender preferences for children. Calverton: Macro International; 1997.

107. DasGupta M, Bhat PNM. Fertility decline and increased manifestation of sex bias in India. Population Stud. 1997;51(3):307.

108. Muhuri P, Menken J. Adverse effects of next birth, gender, Anda family composition on child survival in rural Bangladesh. Popul Stud. 1997;51(3):279-94.

109. Arnold F, Choe MK, Roy TK. Son preference, the family-building process and child mortality in India. Population Stud. 1998;52(3):301-15.

110. Mea C. Son preference, family building process and child mortality. In: Nations U, editor. Too young to die: genes or gender? 1998.

111. Cleland J, Harris K. The effect of maternal education on cild health and survival - do girls benefit? In: Nations U, editor. Too young to die: genes or gender? 1998

112. Timaus HF. Can use of health care explain sex differentials in child mortality in the developing world? In: Nations U, editor. Too young to die: genes or gender? 1998

113. Goodkind D. Do parents prefer sons in North Korea? Stud Fam Plan. 1999; 30(3):212-8.

114. Kikuzawa S. Family composition and sex-differential mortality among children in early modern Japan. Soc Sci Hist. 1999;23(1):99-128.

115. Rose E. Consumption smoothing and excess female mortality in rural India. Rev Econ Stat. 1999;81(1):41-9.

116. Wahab A, Winkvist A, Stenlund H, Wilopo SA. Infant mortality among Indonesia boys and girls: effect of sibling status. Ann Trop Paediatr. 2001; 21(1):66-71.

117. Ashorn P, Maleta K, Espo M, Kulmala T. Male biased mortality among 1-2 year old children in rural Malawi. Arch Dis Child. 2002;87(5):386-7.

118. Modin B. Birth order and mortality: a life-long follow-up of 14,200 boys and girls born in early 20th century Sweden. Soc Sci Med. 2002;54(7):1051-64.

119. Garenne M. Sex differences in health indicators among children in African DHS surveys. J Biosoc Sci. 2003;35(4):601-14.
120. Gleason SM. Publicly provided goods and intrafamily resource allocation: female child survival in India. Rev Dev Econ. 2003;7(1):71-85.

121. Li JH, Lavely W. Village context, women's status, and son preference among rural Chinese women. Rural Sociol. 2003;68(1):87-106.

122. Alter G, Manfredini M, Nystedt P. Gender differences in mortality. In: Bengtsson T, Campbell C, Lee JZ, editors. Life under Pressure: Mortality and Living Standards in Europe and Asia, 1700-1900. Cambridge: The MIT Press; 2004. p. 328-57.

123. Arokiasamy P. Regional patterns of sex bias in child health care and excess female child mortality in India. Population. 2004;59(6):949-82.

124. Li S, Zhu C, Feldman MW. Gender differences in child survival in contemporary rural China: a county study. J Biosoc Sci. 2004;36(1):83-109.

125. Bhargava A. Family planning, gender differences and infant mortality: Evidence from Uttar Pradesh, India. Econometrics, Statistics, and Computational Approaches in Food and Health Sciences; 2006. p. 303-18.

126. Crognier E, Baali A, Hilali MK, Villena M, Vargas E. Preference for sons and sex ratio in two non-western societies. Am J Hum Biol. 2006;18(3):325-34.

127. Fuse K, Crenshaw EM. Gender imbalance in infant mortality: a cross-national study of social structure and female infanticide. Soc Sci Med. 2006;62(2): 360-74.

128. Subramanian SV, Nandy S, Irving M, Gordon D, Lambert H, Smith GD. The mortality divide in India: the differential contributions of gender, caste, and standard of living across the life course. Am J Public Health. 2006;96(5):818-25.

129. Alam N, Ginneken JV, Bosch A. Decreases in male and female mortality and missing women in Bangladesh. In: Attané I, Guilmoto C, editors. Watering the neighbour's garden: the growing demographic female deficit in Asia. Paris: Committee for International Cooperation in National Research in Demography; 2007. p. 161-81.

130. Chen J, Xie Z, Liu H. Son preference, use of maternal health care, and infant mortality in rural China, 1989-2000. Popul Stud (Camb). 2007;61(2):161-83.

131. Ueyama M. Income growth and gender bias in childhood mortality in developing country; 2007.

132. Jayaraj D. Exploring the importance of excess female mortality and discrimination in "natality" in explaining the "lowness" of the sex ratio in India. Developing Economies. 2009;47(2):177-201.

133. Maitra P, Rammohan A. The link between infant mortality and child nutrition in India: is there any evidence of a gender bias? J Asia Pac Econ. 2011;16(1):81-110.

134. Silverman JG, Decker MR, Cheng DM, Wirth K, Saggurti N, McCauley HL, et al. Gender-based disparities in infant and child mortality based on maternal exposure to spousal violence: the heavy burden borne by Indian girls. Arch Pediatr Adolesc Med. 2011;165(1):22-7.

135. Balsara SL, Faerber JA, Spinner NB, Feudtner C. Pediatric mortality in males versus females in the United States, 1999-2008. Pediatrics. 2013;132(4):631-8.

136. Jamison DT, Summers LH, Alleyne G, Arrow KJ, Berkley S, Binagwaho A, et al. Global health 2035: a world converging within a generation. Lancet. 2013;382(9908):1898-955.

137. Krishnan A, Dwivedi P, Gupta V, Byass P, Pandav CS, Ng N. Socioeconomic development and girl child survival in rural North India: solution or problem? J Epidemiol Community Health. 2013;67(5):419-26.

138. Monden CWS, Smits J. Maternal education is associated with reduced female disadvantages in under-five mortality in sub-Saharan Africa and southern Asia. Int J Epidemiol. 2013;42(1):211-8.

139. Pham TL, Kooreman P, Koning RH, Wiersma D. Gender patterns in Vietnam's child mortality. J Popul Econ. 2013;26(1):303-22.

140. Pongou R. Why is infant mortality higher in boys than in girls? A new hypothesis based on preconception environment and evidence from a large sample of twins. Demography. 2013;50(2):421-44.

141. Rosenblum D. The effect of fertility decisions on excess female mortality in India. J Popul Econ. 2013;26(1):147-80.

142. Rosenstock S, Katz J, Mullany LC, Khatry SK, LeClerq SC, Darmstadt GL, et al. Sex differences in neonatal mortality in Sarlahi, Nepal: the role of biology and environment. J Epidemiol Community Health. 2013;67(12):986-91.

143. Boco AG. Assessing sex differentials in under-five mortality in subSaharan Africa: a cross-national comparative analysis. Can Stud Popul. 2014;41(4):49-87.

144. Steen EE, Kallen K, Marsal K, Norman M, Hellstrom-Westas L. Impact of sex on perinatal mortality and morbidity in twins. J Perinat Med. 2014;42(2):225-31.

145. Flato M, Kotsadan A. Droughts and gender bias in infant mortality in subSaharan Africa. Memorandum; 2015. 
146. Guilmoto CZ. Mapping the diversity of gender preferences and sex imbalances in Indonesia in 2010. Popul Stud. 2015;69(3):299-315.

147. Nandi A. The unintended effects of a ban on sex-selective abortion on infant mortality: evidence from India. Oxf Dev Stud. 2015;43(4):466-82.

148. Altindag $\mathrm{O}$. Son preference, fertility decline, and the nonmissing girls of Turkey. Demography. 2016;53(2):541-66.

149. Chowdhury R, Taneja S, Mazumder S, Bhandari N, Strand TA. Gender differences in infant survival: A secondary data analysis in rural North India. BMJ Open. 2017;7(8).

150. Kalsi P. Seeing is believing- can increasing the number of female leaders reduce sex selection in rural India? J Dev Econ. 2017;126:1-18.

151. Pongou R, Defo BK, Dimbuene ZT. Excess male infant mortality: the geneinstitution interactions. Am Econ Rev. 2017;107(5):541-5.

152. Zhao D, Zou L, Lei X, Zhang Y. Gender differences in infant mortality and neonatal morbidity in mixed-gender twins; 2017.

153. Guilmoto CZ, Saikia N, Tamrakar V, Bora JK. Excess under-5 female mortality across India: a spatial analysis using 2011 census data. Lancet Glob Health. 2018;6(6):e650-e8.

154. Iqbal N, Gkiouleka A, Milner A, Montag D, Gallo V. Girls' hidden penalty: Analysis of gender inequality in child mortality with data from 195 countries. BMJ Glob Health. 2018;3(5):e001028.

155. Stephenson R, Tharp MB, Wiginton JM, Metheny N. Sex composition of twins and associations with morbidity, mortality and maternal treatment-seeking outcomes in resources-poor settings. J Biosoc Sci. 2018;50(4):491-504.

156. Diamond-Smith N, Saikia N, Bishai D, Canudas-Romo V. What has contributed to improvements in the child sex ratio in select districts of India? A decomposition of the sex ratio at birth and child mortality. J Biosoc Sci. 2020;52(1):27-36. https://doi.org/10.1017/S0021932019000221.

157. Coale AJ, Demeney P. Regional model life tables and stable population. Princetion, NJ; 1966.

158. Coale AJ, Demeney P. Regional Model Life Tables and Stable Population. New York; 1983

159. Jeffery $R$, Jeffery $P$, Lyon A. Female infanticide and amniocentesis. Soc Sci Med. 1984;19(11):1207-12.

160. Premi MK. Female infanticide and child neglect as possible reasons for low sex ratio in the Punjab, 1881-1931. Population Geography. 1994; 16(1-2):33-48

161. Ismail SA, McCullough A, Guo S, Sharkey A, Harma S, Rutter P. Genderrelated differences in care-seeking behaviour for newborns: a systematic review of the evidence in South Asia. BMJ Global Health. 2019:4:e001309.

162. Gupta MD, Zhenghua J, Bobua L, Zbenming X, Wi C, Hwa-Ok B. Why is son preference so persistent in East and South Asia? A cross-country study of China, India, and the Republic of Korea; 2002.

163. Jones N, Harper C, Watson C, Espey J, Wadugodapitiya D, Page E, et al. Son Bias. In: Centre TCPR, editor. Stemming girls' chronic poverty: catalysing development change by building just social institutions; 2010.

164. Murray CJ, Ezzati M, Flaxman AD, Lim S, Lozano R, Michaud C, et al. Comprehensive systematic analysis of global epidemiology: definitions, methods, simplification of DALYs, and comparative results from the global burden of disease 2010 study. Lancet. 2012;380:1-131.

165. Anand S, Reddy SG. The construction of the DALY: implications and anomalies. Working paper 34; 2019.

\section{Publisher's Note}

Springer Nature remains neutral with regard to jurisdictional claims in published maps and institutional affiliations.

Ready to submit your research? Choose BMC and benefit from:

- fast, convenient online submission

- thorough peer review by experienced researchers in your field

- rapid publication on acceptance

- support for research data, including large and complex data types

- gold Open Access which fosters wider collaboration and increased citations

- maximum visibility for your research: over $100 \mathrm{M}$ website views per year

At $\mathrm{BMC}$, research is always in progress.

Learn more biomedcentral.com/submissions 